Revue Gouvernance

Governance Review

GOUVERNANCE

(G) ERNAN N Eme

\title{
Ethiopia: Natural Resource Exploitation and Emerging Investors
}

\section{Hany Besada}

Volume 14, numéro 1, 2017

URI : https://id.erudit.org/iderudit/1040637ar

DOI : https://doi.org/10.7202/1040637ar

Aller au sommaire du numéro

\section{Éditeur(s)}

Centre d'études en gouvernance de l'Université d'Ottawa

ISSN

1912-0362 (numérique)

Découvrir la revue

Citer cet article

Besada, H. (2017). Ethiopia: Natural Resource Exploitation and Emerging Investors. Revue Gouvernance / Governance Review, 14(1), 66-87. https://doi.org/10.7202/1040637ar

\section{Résumé de l'article}

La gouvernance des ressources naturelles accélère le développement. L'Éthiopie, un pays à faible revenu, a adopté une législation foncière dans les années 1990 et a ensuite affiché une croissance économique exceptionnelle et des améliorations au développement humain. De 2004 à 2014, le taux de croissance annuel moyen du PIB de l'Éthiopie était d'environ de neuf pour cent. Néanmoins, plus de $80 \%$ de la population restent en insécurité alimentaire. À l'aide d'une revue de littérature et d'entretiens, cette étude de cas examine le développement économique et social de l'Éthiopie sous l'angle de la gouvernance foncière. Elle vise à documenter les défauts dans le cadre réglementaire de l'Éthiopie qui empêchent les communautés vulnérables de tirer parti des avantages des investissements étrangers directs (IDE) plus élevés et de la croissance économique qui en résulte. Le cas analyse le cadre de gouvernance agricole de l'Éthiopie et l'impact de l'agriculture à grande échelle axée sur les IDE sur les petites exploitations agricoles et conclut avec des suggestions d'approches d'investissement alternatives. L'étude de cas révèle que la législation du gouvernement éthiopien et la croissance macroéconomique qui en résulte n'ont pas encore permis de générer des gains économiques inclusifs et stables pour de nombreux petits paysans vulnérables. Il est nécessaire de proposer de nouvelles réglementations et politiques qui non seulement protègent ces communautés vulnérables, mais aussi améliorent les incitations économiques et commerciales pour les investisseurs étrangers potentiels. 


\title{
Ethiopia: Natural Resource Exploitation and Emerging Investors ${ }^{1}$
}

\author{
By Hany Besada ${ }^{i i i}$
}

\begin{abstract}
Natural resource governance accelerates development. Ethiopia, a low-income country, passed land legislation in the 1990s and subsequently exhibited exceptional economic growth and human development improvements. From 2004 to 2014, Ethiopia's average annual GDP growth rate was about nine per cent. Nevertheless, over $80 \%$ of the population remain food insecure. Using a literature review and interviews, this case study examines Ethiopia's economic and social development through a land governance lens. It aims to document the flaws in Ethiopia's regulatory framework that hinder vulnerable communities from leveraging the benefits of greater foreign direct investments (FDI) and resultant economic growth. The case analyzes Ethiopia's agricultural governance framework and the impact of FDI-driven large-scale farming on smallholder communities, and concludes with suggestions for alternative investment approaches. The case study reveals that Ethiopian government legislation and resultant macroeconomic growth has yet to deliver inclusive and stable economic gains for many of the vulnerable smallholder communities. There is a need to advance further regulation and policies that not only protect these vulnerable communities, but also enhance economic and trade incentives for potential foreign investors.
\end{abstract}

Keywords: Natural resource governance, foreign direct investment, farmers, Ethiopia, agriculture

\section{Résumé}

La gouvernance des ressources naturelles accélère le développement. L'Éthiopie, un pays à faible revenu, a adopté une législation foncière dans les années 1990 et a ensuite affiché une croissance économique exceptionnelle et des améliorations au développement humain. De 2004 à 2014, le taux de croissance annuel moyen du PIB de l'Éthiopie était d'environ de neuf pour cent. Néanmoins, plus de $80 \%$ de la population restent en insécurité alimentaire. À l'aide d'une revue de littérature et d'entretiens, cette étude de cas examine le développement économique et social de l'Éthiopie sous l'angle de la gouvernance foncière. Elle vise à documenter les défauts dans le cadre réglementaire de l'Éthiopie qui empêchent les communautés vulnérables de tirer parti des avantages des

1 The author would like to thank Ms. Vasundhara Saravade and Mugambwa Joshua for research assistance on the paper. 
investissements étrangers directs (IDE) plus élevés et de la croissance économique qui en résulte. Le cas analyse le cadre de gouvernance agricole de l'Éthiopie et l'impact de l'agriculture à grande échelle axée sur les IDE sur les petites exploitations agricoles et conclut avec des suggestions d'approches d'investissement alternatives. L'étude de cas révèle que la législation du gouvernement éthiopien et la croissance macroéconomique qui en résulte n'ont pas encore permis de générer des gains économiques inclusifs et stables pour de nombreux petits paysans vulnérables. Il est nécessaire de proposer de nouvelles réglementations et politiques qui non seulement protègent ces communautés vulnérables, mais aussi améliorent les incitations économiques et commerciales pour les investisseurs étrangers potentiels.

Mots clés: Gouvernance des ressources naturelles, investissement étranger direct, agriculteurs, Éthiopie, Agriculture

\section{Introduction}

Natural resource governance often provides a lens into the development and decentralization of a local democracy or region, but is frequently overlooked as a purely management issue (Ribot, 2003). A decentralized approach allows for effective accountability in the management and governance of natural resources, while also keeping in mind the importance of local context and stakeholders. This case study looks at one such governance issue by addressing Ethiopia's economic and social development through a natural resource lens, with an emphasis on the challenges posed by food security for its highly vulnerable population.

Although the Ethiopian government has been developing agricultural legislation over the past few decades to support its vulnerable population-especially smallholder farmers and pastoralists - there is a need to advance further regulations and policies that not only protect these communities, but enhance economic and trade incentives for potential foreign investors. Food-related foreign direct investment (FDI) projects and trade relationships can be controversial, as demonstrated by the growing phenomenon of land grabs and food insecurity in food-exporting countries. In view of this, there is a critical need to build bilateral agricultural investment and trade models that exhibit deep consideration for local land governance contexts, bolster food security, and foster prosperity in both countries, particularly for marginalized individuals.

Factors such as Ethiopia's agricultural governance framework, the impact of FDI-driven large-scale farms on smallholder farmers and pastoralists, and alternative investment approaches will be discussed in the following sections. The final section will offer 
additional analysis and recommendations for building an inclusive and sustainable investor- and community-driven Ethiopian agricultural model. The aim of this study is to document those flaws in the Ethiopian regulatory framework that prevent its vulnerable communities, such as the smallholders and pastoralists, from leveraging the benefits of increasing foreign agricultural investments over the past few years. It is therefore also necessary to address the role that investor state governments can play in tackling regulatory and socio-economic challenges in the governance and management of natural resources in Ethiopia.

\section{Ethiopia's Agricultural Governance Framework}

Given that land is a fundamental input in agricultural production, this section provides a snapshot of Ethiopia's current land governance framework and its historical context to better understand how it would support or undermine a sustainable bilateral investment and trade model.

\subsection{The Nationalization and Redistribution of Land}

Ethiopia was ruled for many centuries by an imperial regime, in which land ownership was governed by a quasi-feudal structure. In 1974, after a popular uprising overthrew the last emperor, a Communist military regime took power and reconfigured the country's land tenure system. In furtherance of the uprising's premise of eliminating the elite, the new government redistributed land to smallholder farmers through newly created local Peasant Associations. Thus, with the government's enactment of the Public Ownership of Rural Lands Proclamation in 1975, all land was nationalized and redistributed. The Proclamation granted Peasant Associations the power to redistribute land whereby individual peasants could access parcels of up to ten hectares per household (Government of Ethiopia, 1975, chap. 3). Under this new scheme, Ethiopian households were granted usufruct rights, meaning that private land ownership or its transfer by sale, lease, rental, or mortgage was strictly prohibited (Government of Ethiopia, 1975, chap. 2).

\subsection{Empowering Vulnerable Smallholders, Certifying Land Rights, and Agricultural Development-Led Industrialization}

The mid-1980s to the mid-1990s was marked by a crisis of agrarian stagnation and decline in Ethiopia and the greater Sub-Sahara African region, due in large part to a range of failed land policies, and so many African governments again pursued land reform. In light of a new human focus, rather than strictly economic development, certain Western institutions prescribed land policy reforms that placed a greater focus on customary, indigenous, and women's rights over private, individual ownership. As the Cold War waned, a wave of democratization also swept over various parts of world, with decentralization advocates arguing that through accountable local leadership, 
communities could properly manage their own resources and achieve significant increases in agricultural production and productivity (Boone, 2007).

Agricultural stagnation contributed to the overthrow of Ethiopia's Communist regime in 1991, replaced by the country's current ruling party, Ethiopian People's Revolutionary Democratic Front. While this regime differed from the previous one by establishing a new federal system that devolved land administration to ethnically delineated regional governments, it also upheld the major pillars of the 1975 land policy. Land continued to be owned by the state and was administered to the Ethiopian population through local institutions. Thus, Ethiopians retained usufruct rights to their land, although minor changes included a provision that outlined land-access rights contingent on a landholder's continued residence in the sub-district and their personal engagement in the agricultural management of that land (Interview, Embassy of Australia in Ethiopia, 1 July 2015).

The new regime's land policy was codified in Ethiopia's 1995 Constitution, and, in following with international trends, also upheld and created an increased focus on land rights for vulnerable smallholder groups. Article 40 (5) entitled Ethiopian pastoralists to "the right to free land for grazing and cultivation as well as the right not to be displaced from their own lands," while Article 35 (7) granted women "equal rights with men with respect to use, transfer, administration and control of land" and "equal treatment in the inheritance of property." The creation of an ethnic-based federalist model, whereby nine regional territories and governments were established based on ethnic criteria, was hailed by the international community as a means of allowing ethnic self-determination. By creating ethnically delineated regional governments, especially those governing more marginalized populations, the government argued that there was greater ethnic equality in terms of government representation.

One of the most notable responsibilities of these new regional governments was the administration of land within their territories, a role similar to that of the Peasant Associations under the previous regime. While land legislation was still under the mandate of the federal government, regional counterparts oversaw corresponding laws and guidelines on how federal laws, proclamations, regulations, and directives were implemented. Consequently, each region addressed land administration slightly differently in order to cater to local context.

Years after the establishment of the 1995 Constitution, the Ethiopian government also sought to introduce a land certification program aimed at reducing tenure insecurity and its negative impact on agricultural investment. Beginning in 2003 and over the course of five years, the Ethiopian government registered roughly 25 million rural parcels in four 
of its main regions. According to the World Bank, this participatory, pro-poor, and gender-sensitive certification program was "one of the largest, fastest, and most low effective processes globally" (Deininger, Selod, \& Burns, 2011, p. 6).

Meanwhile, the new government also pursued complementary agricultural development policies that were highly supportive of smallholders. Its Agricultural Development-Led Industrialisation (ADLI) strategy asserted that because Ethiopia was a labour-rich and capital-poor country, the government should cater to and support its most labourintensive industry through inputs such as irrigation, fertilizer, improved seeds, credit services, and capacity development programs. The government posited that increased support for the agricultural sector could generate economic growth while improving national food security and stimulating downstream and upstream agricultural linkages. One of the key pillars of this strategy was land-access security for vulnerable smallholders, which the government argued enabled the prevention of land transfers often negotiated by poorer households during times of distress.

\subsection{Unfulfilled Expectations}

Five to ten years after the enactment of the 1995 Constitution and these agricultural policies, agricultural growth, poverty, and food security had yet to show any significant changes. Additionally, growth in forward and backward production linkages were limited due to a lack of demand and shortage of both public funds and capital accumulation in the private sector. This limited the larger investments needed to facilitate these linkages. Consequently, doubts were raised about the economic arguments outlined in the ADLI that favoured focusing on smallholder agriculture as an engine for growth. These doubts convinced senior Ethiopian policymakers that an expanded agricultural approach was required (Interview, Addis Ababa Chamber of Commerce, 16 April 2014).

In addition to limited economic impacts, these new land and agricultural polices also failed with regards to protecting vulnerable groups, as demonstrated by the continued political marginalization of lowland regions, despite legal recognition of ethnic equality through federalism. After a long history of inequality under imperial rule, during which the "lowland periphery was characterised by inequality, exploitation and extraction of resources through collection of tribute and taxes, and the slave and ivory trades" (Lavers, 2012b, p. 125), the ethnic groups indigenous to these regions, such as the Anuak, Afar, and Somali, were left with few skills or experience to administer their territory under the new ethno-federalist model. As a result, in many cases the central government continued to act on these regions' behalf in governing their territories. Pastoralists and shifting cultivators within these regions were also denied "their right not to be displaced from their own land" (Government of Ethiopia, 2015, Article 40 [5]), as the state began to 
expropriate their land under the guise of it being "unused," despite its crucial role in the nomadic nature of pastoralism and shifting agriculture. Ethiopia's "gender-sensitive" land certification program also had varying impacts in strengthening women's rights, with an overwhelming $70.51 \%$ of land certificates in the Amhara region, for example, assigned to husbands only.

Furthermore, Ethiopia's land certification program's impact on smallholder tenure security was stunted due to lingering tenure concerns. While the program's resulting certificates had some positive effects on tenure security and other outcomes, such as landrelated investment, a certain level of land insecurity continued. Given the growing levels of landlessness in certain regions, Ethiopian landholders worried that future land redistributions would occur (Ali, Dercon, \& Gautam, 2007). They also realized that even with a land certificate in hand, the government could still legally expropriate land when it deemed necessary (Rahmato, 2011).

\subsection{Shift Towards Large-Scale Farming, FDI, and Agricultural Trade}

In view of these challenges, in the early 2000s the federal government began to expand its focus on smallholder production and internal production linkages to include largescale commercial agriculture, trade, and foreign investment. The ADLI strategy previously hailed by the government was superseded by this new strategy and the significant economic growth it was predicted to spur (Interview, Addis Chamber of Commerce, 16 April 2014). This policy shift was demonstrated most significantly in 2002 and 2003 with the enactment of investment proclamations and new regulations governing incentives for foreign and domestic investors (Rahmato, 2011).

These new legislative tools were notably generous to foreign investors. Although foreign investors had typically been prohibited from leasing land in Ethiopia for more than 2550 years, the new legislation largely exempted this group from taxes on imports of capital goods as well as repatriated profits on taxes (Bossio et al., 2012). Additionally, Ethiopian land is leased for very low rents, with the lowest fees available in the remote and sparsely populated lowland regions. As the Ministry of Agriculture (formerly the Ministry of Agriculture and Rural Development) stated in 2009, Ethiopia offers negligible lease rates compared to the surrounding region (Makki, 2012). Consequently, these incentives, combined with, in many cases, a superficial approval process for investment proposals, have been criticized for the lack of advantages and economic return they create for Ethiopians.

Since these changes to Ethiopia's laws, this low-income country has exhibited exceptional economic growth and human development improvements. With an average annual GDP growth rate of roughly nine per cent between 2004 and 2014 (World DataBank, 2016b), 
and as one of the 10 countries globally that has attained the largest absolute gains in Human Development Index (HDI) over the last several years, Ethiopia has garnered significant attention from the international community.

However, despite these gains, not all Ethiopians have benefited from this economic growth. Livelihoods of Ethiopian farmers and pastoralists, which account for over $80 \%$ of the population (Ali et al., 2007), remain precarious due to a lack of transformation in the smallholder agricultural sector. Since 2016, droughts across the country have caused 10.2 million Ethiopians to require emergency food relief (World Food Program, 2016), up roughly 65\% from the 6.2 million Ethiopians in need in 2009 (Bues \& Theesfeld, 2012, p. 269). This food insecurity is both caused and compounded by the fact that, since 2011, average per capita income levels have been low as 3 Birr ( $\$ 0.14$ US Dollars) per day in some areas-a significant destabilizer to smallholder resilience in the face of potential external shocks (Shepherd, 2013, p. 7). As such, Ethiopia's macroeconomic growth has yet to deliver inclusive and stable economic gains for many of its more vulnerable populations.

\section{Impact of FDI-Driven Large-Scale Farms on Smallholder Farmers and Pastoralists} FDI-driven large-scale farming projects in SSA have raised serious concerns due to the speed at which these investments are growing and the unregulated nature of the transactions. Although foreign interest in African agricultural land is not new, this most recent and more notable international rush for African land began after grain prices soared in 2007 and 2008, provoking food-importing countries to re-evaluate their longterm food security. This event, coupled with a new goal of increasing the use of biofuels and the growth of carbon markets, spurred renewed interest in African land among capital-rich governments, transnational companies, and capital investment managers (Woertz, 2013). Many of these transactions have been termed "land grabs," given that they are notably unjust to the suppliers - typically pastoralists and smallholder farmers. However, Ethiopia has become a magnet for FDI - with 32\% dedicated to the agricultural sector-and the government openly promotes investments in large-scale farms. This section explores some of the pitfalls of such large-scale farming and how current investment models have negatively impacted Ethiopian smallholder farmers and pastoralists. This section also analyzes how alternative models could aid in overcoming some of these challenges in searching for sustainable and inclusive bilateral investment frameworks.

\subsection{Large-Scale Farming Pitfalls}

The Ethiopian government has shown increasing support for large-scale farming projects - funded mostly by foreign investors, given the lack of capital formulation in Ethiopia's private sector-arguing that this new model will benefit smallholder 
producers. Stated benefits include the creation of employment opportunities, development and improvement of rural infrastructure, arrival of new sources of knowledge transfer, and lucrative sale opportunities for African farmers looking to invest capital in other industries.

Mainstream Western and African regional development institutions, such as the World Bank and the Alliance for a Green Revolution in Africa (AGRA), have presented this commercial shift from small-scale agricultural production to large-scale commercial farming as an essential step in improving agricultural productivity. Within the terms of this discourse, the stagnation of African agriculture is attributable to the persistence of smallholder farms; the only way to overcome this is through greater mechanization of agricultural operations and the economies of scale offered through large-scale farming.

Yet, even as yields and agricultural productivity in Africa have increased due to this commercialization strategy, so has hunger and poverty. Elsewhere, such as in Central America, agricultural modernization has produced similar results because large-scale production tends to offer "fewer socio-economic and enabling stimuli than other organisational forms" (Baumgartner, 2012, p. 188).

The non-inclusive growth model is, in many ways, caused by the nuanced weaknesses of the large-scale farming model. For instance, running counter to the expectation of employment creation, commercial agriculture tends to replace labour-intensive smallholder farming techniques with capital-intensive technology. Large-scale commercial farming is also likely to degrade the surrounding environment and decrease the sustainability of nearby agricultural production due to its intensive use of freshwater ways, fertilizers, pesticides, and fossil fuels for machinery (Vermeulen \& Cotula, 2010; Anseeuw, 2013). The United Nations Special Rapporteur on the Right to Food also noted that a significant loss of agro-biodiversity is typically associated with large-scale monocultures (Özden, 2013). This weakens not only stability and productivity, but also the resilience of agricultural systems in the face of weather- and pest-related shocks. According to Altieri and Nicholls (2008), poly-cultural agricultural techniques offer yield advantages of $20-60 \%$ because they "reduce losses due to weeds, insects and diseases, and make a more efficient use of the available resources of water, light and nutrient" (p. 474). As such, there is a growing recognition that more balance is needed within the Western "modernized" approach to agriculture, as the current one may worsen the potential for ecological shocks, environmental damage, and further marginalization of the majority of the world's agricultural population.

Smallholder farming, in contrast, typically emphasizes ecological diversity, systems integration, and synergies, as well as the inclusion and development of poor 
smallholders. For instance, smallholder farming generates more jobs than large-scale farms due to its lack of mechanization (Herren, Bassi, Tan, \& Binns, 2012). It also allows for higher aggregate production levels per unit of land due to its use of crop diversification. Furthermore, smallholder farming delivers greater returns due to its associated agricultural techniques that produce high yields with fewer inputs. Similarly, migratory livestock or shifting agricultural production offers the spatial flexibility needed for arid or semi-arid climates. In allowing herds of livestock to move over great distances, or rotate cultivation through different plots of land, pastoralism and shifting cultivation offer important benefits to populations in areas where rainfall-meaning the availability of water and fodder - is variable (van den Brink, 2006).

\subsection{Ethiopia's Increasing Allocation of Land to Foreign Investors for Large-Scale Farms}

As outlined in the previous section, despite these weaknesses the Ethiopian government has created multiple incentives to boost foreign investor demand. As reflected in Figure 1, the total area solicited annually by foreign investors, which did not exceed 50,000 hectares prior to 2003, surpassed 500,000 hectares by 2004 . Although there were short drops after national elections in 2005 and during the food price crisis of 2008, overall the share of foreign investments in Ethiopian land has been growing since the early 2000s.

Figure 1: Total Land Area Requested Annually (1992 - 2010) in Ethiopia by Inverstor Category

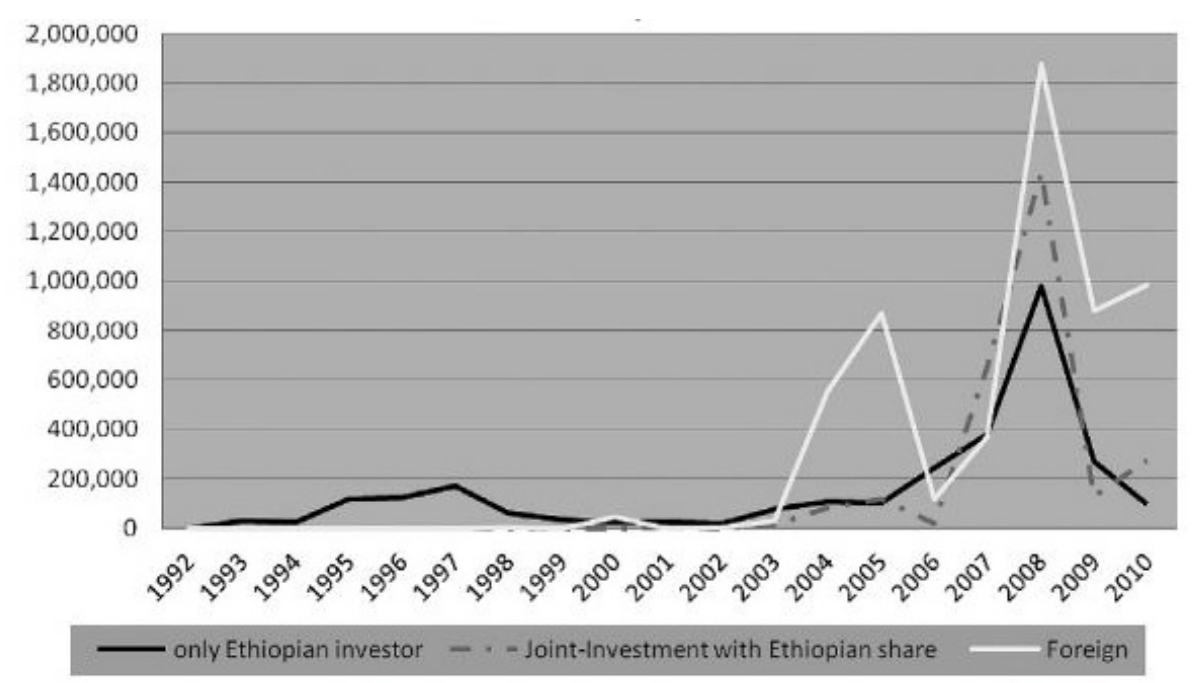

Source: Baumgartner et al., 2015.

According to the Ethiopian Investment Agency, three-and-a-half-million hectares of land were allocated for large-scale lease investments between 1996 and 2008 (Interview, Ethiopia Investment Agency, 17 April 2014), As highlighted in Figure 2, much of this was made available in the remote lowland areas in the west and south of the country. Figure 
2 also shows that an increasing portion of land was allocated specifically in the lowland regions of Benishangul-Gumuz, Gambella, and Southern Nations, Nationalities, and Peoples' Region (SNNPR).

Figure 2: Land Leased to Investors (in thousands of hectares) in Ethiopia by village

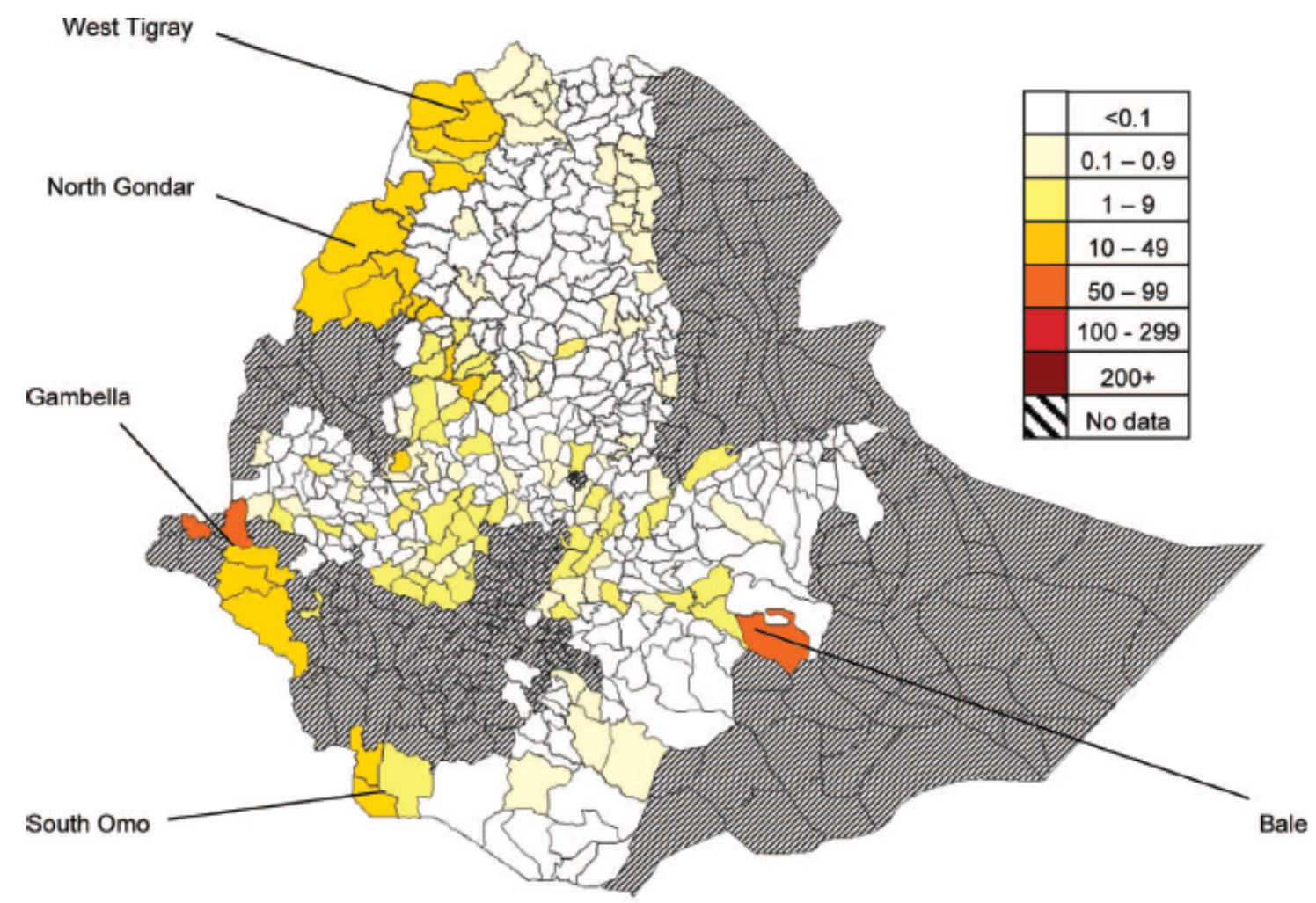

Source: Lavers, 2012a.

Despite the economic benefits stated by the government, many foreign large-scale land investments have negatively affected local populations. For example, in the case of knowledge spillovers, in Ethiopia there are no investor regulations that require the hiring of local labour (Interview, Ethiopia Investment Agency, 17 April 2014). As such, not all projects provide employment opportunities, and many who are employed are offered casual contracts, meaning they have little employment security (Rahmato, 2011). For example, according to data taken from the Embassy of India in Ethiopia, more than $90 \%$ of the 110,000 Ethiopian workers employed by Indian agriculture projects in 2008 were seasonal workers (Shepherd, 2013, p. 9). One project in the lowlands also demonstrated the tension between indigenous lowland labour and that of a growing group of highland seasonal migrant farmers who were willing to move for agricultural work (Moreda, 2015). In this case, the indigenous group was displaced from their ancestral lands for the benefit of a foreign investor, yet were then marginalized in the subsequent hiring of local 
labour. This was confirmed separately by the European Union (EU) Delegation to Ethiopia, which noted that most commercial farms hired foreign workers or workers from outside the local community, generating tensions between local and migrant groups (Interview, EU Delegation to Ethiopia, 11 April 2014).

Looking beyond knowledge transfer and employment opportunities, the construction of rural infrastructure, such as new roads and irrigation networks (a transactional obligation in many land deals), can be important trade-offs for affected communities that sell their land or relocate to make way for large-scale agricultural investments. In contrast to other countries, however, Ethiopia's infrastructure requirements for investors are minimal. According to a private investor in one case study, the Ethiopian government was responsible for all public infrastructure (i.e., roads, telecommunications, and electricity). The investing company provided private infrastructure, such as roads and irrigation systems internal to the investment area, and accommodation for its employees (Shepherd, 2013). In another study, the investing company's only infrastructure investment obligations were to repair and widen a dirt track leading to the project site, as well as provide some plastic sheeting to a community school (Rahmato, 2011). Yet, even then, there was little benefit to the community as the investor cut down various fruit trees to widen the road-thereby eliminating an essential source of food security and income - and refused to compensate affected smallholders. In sum, a lack of investment regulations regarding contribution requirements to Ethiopia's infrastructure has significantly diminished the potential returns of these investments for affected smallholders.

With regards to food security, it is important to note that 10.2 million Ethiopians were in need of emergency food relief in 2016 (WFP, 2016). Despite this, the Ethiopian government's incentives for foreign investors were extremely liberal, if not counterproductive with regards to the country's food security. For example, investments are given higher priority through additional tax exemptions for investors if their crops are destined for the export market (Lavers, 2012a). According to Article 4 of the Council of Ministers Regulation No. 84/2003, which stipulates new investment incentives, investors engaged in "manufacturing or agro-industrial activities or the production of agricultural products" are exempt from income tax for at least five years if they export more than half their production or provide $75 \%$ to exporters. In contrast, those exporting less than $75 \%$ of their production are only exempt for a minimum of two years (EMFED $\& N B, 2010)$.

In addition to these generous tax incentives, there has been a massive shift of land and water rights from customary to foreign users, a process that often happens informally as a result of ambiguous land rights (discussed earlier) and water regulations. In one case 
study in Oromia, newly arrived foreign investors from the Netherlands, Russia, Israel, Palestine, and China initiated changes to the community's previously informal rights to canal infrastructure (Bues \& Theesfeld, 2012). Smallholder needs were neglected in the face of these more powerful investors, who were able to divert water and use other traditionally communal sources. Communal land in another project, in which Saudi Star was given land and water rights to develop a large-scale project on Annuak land in the Gambella region, was similarly expropriated due to the perception that it was unused (Rahmato, 2011). However, this land was far from unused, as the Annuak people supplement their smallholder farming incomes with fishing, hunting, and honey production, relying on their surrounding ecosystem for wild food sources in times of hardship. As a result, Saudi Star's deforestation of this previously communal land has worsened the local community's food security (Rahmato, 2011).

Looking at the impacts of large-scale land investments from a political perspective, there is typically a lack of engagement with local populations when deciding whether an investor can acquire land near or in their community. Smallholders and pastoralists alike in several parts of the country have consequently demonstrated overt resistance through peasant protests. They have also exhibited covert forms of resistance, such as gradual encroachments on land given to investment projects and the quiet destruction of field crops and machinery (Rahmato, 2011). The people of the Godere woreda in the Gambella region, for example, organized a series of meetings after they heard that an Indian company called Lucky Exports had acquired a lease of 5000 hectares of forest to establish a tea plantation near their community (Rahmato, 2011). They prepared and took to the federal government an alternative land-use plan that would preserve the forest and provide youth employment. The community successfully lobbied to halt the plantation project, but resistance, let alone successful protests, has since become the exception to the rule in the Gambella region (Horne \& Bader, 2012).

According to the 2012 World Report published by Human Rights Watch (HRW), since 2008 at least 3.6 million hectares in the Gambella region have been leased to multinational and local firms, much of which has been orchestrated with the help of armed security forces driving people from their land (Horne \& Bader, 2012). According to the report, tens of thousands of indigenous people have been forcibly moved from their homes in Gambella to new villages without any meaningful consultation or prior consent. Although the stated goals of what should be a voluntary "villagization" program are to provide better access to basic infrastructure and agricultural assistance, the program has mostly taken place in areas where significant land investments have already occurred or will likely be made (Horne \& Bader, 2012). After interviewing over 100 residents in Gambella who had been impacted by the villagization program, HRW stated that it found 
"widespread human rights violations at all stages of the programme" (Horne \& Bader, 2012).

With regards to the Ethiopian's government's provision of compensation for expropriated land, Lavers (2012a) observed that, on the whole, displaced smallholders "seem to receive the legally required compensation of ten times the average annual income over the previous five years" (p. 907). However, he also noted that it is questionable whether this amount is sufficient. Some farmers do not have the financial capacity to handle a significant amount of money, having never done so before. According to one Ethiopian farmer interviewed in 2011, "the Birr lasted a few months, but the land has been lost for generations" (Shepherd, 2013, p. 9). Multiple projects have further demonstrated the potential divisive effects of compensation when given without adequate consideration of local context (Shepherd, 2013). For example, one largely Amharic village in the predominantly Oromo region of Bishoftu did not receive the intended compensation from an investor because the local Oromo authorities denied payment (Shepherd, 2013). In cases like this, large-scale land leases were used by dominant ethnic groups to exert power over other groups through disproportionate allocations of land or imbalanced distribution of compensation payments.

\section{Alternative Investment Approaches for Consideration}

The current model of large-scale land investments in Ethiopia, whereby foreign investors are given free reign to acquire land for projects without consulting or compensating local communities, has had an overwhelmingly negative impact on smallholder farmers and pastoralists. It is therefore important to consider what opportunities alternative investment models might bring. A lack of diversification in smallholder and pastoral incomes places a significant constraint on agricultural resilience and growth. Although this diversification usually occurs through off-farm income sources, most industrial and service sectors in Ethiopia are lacking in terms of secure job opportunities (FAO et al., 2015). Given Ethiopia's existing agricultural expertise, large-scale farms have been considered low-hanging fruit in terms of creating alternative sources of secure off-farm income. However, the complexities in creating the right balance between commercial farming opportunities and meeting existing smallholder and pastoral needs should not be underestimated. As outlined above, large-scale commercial farms in Ethiopia have thus far had little success in improving the position of smallholder or pastoral producers due to missed opportunities with regards to the creation of highly paid and skilled jobs and investments in locally relevant infrastructure. Likewise, there has been little consideration for the food security of both the country and local populations, or for proper consultation with and compensation for affected communities. 


\subsection{Job Market Issue}

Labour-intensive agricultural crops and/or labour-intensive investment models, as well as the revalorization of local agricultural knowledge, are some potential ways of adapting the current large-scale farm investment model to address the need for highly paid and skilled jobs. Given that the harvest of certain crops, such as cotton, rice, and legumes, is more labour intensive than others, the focus on production of these crops might help large-scale farms soak up excess agricultural labour. Additionally, certain investment models, such as contract farming, enable the labour-intensive model of smallholder farming to continue unchecked, while also expand smallholder access to relevant markets. Indeed, there is an emerging trend among governments whereby investors are required to contribute to local development not only through job provision, environmental protection, and social investments, but also through direct involvement of local farmers and small-scale businesses in the supply chain (Cotula, Vermeulen, Leonard, \& Keeley, 2009). Seeking and integrating traditional agricultural knowledge to navigate a region's ecological conditions and local knowledge of socio-political dynamics of the affected communities opens up opportunities for higher-paid, skilled jobs for local populations.

Certain types of contract farming models have also been tested in Ethiopia with the intent of leveraging their ability to create a higher demand for labour than traditional largescale farm operations. One investment project, for example, established by Israeli managers with financing from European investors on roughly 8000 hectares of land in East Hararghe in 2007, negotiated labour-intensive outgrower schemes (e.g., contract farming), with elders acting on behalf of local communities. By 2008, the project covered 72,000 hectares under the production of an estimated 84,000-124,000 smallholders. However, outgrower contracts based on fixed pricing and unexpectedly low yields in certain growing areas eventually led to the collapse of the operation and caused the managers to flee the country (Lavers, 2012a). Smallholder outgrowers in this type of arrangement are exposed to variations in the cost of living and agricultural inputs, indicating that it is in their best interests not to establish contracts with fixed pricing. Outgrowers also have little bargaining power in negotiating pricing, which, as Lavers' case study demonstrated, cannot be overcome via the forced creation of smallholder cooperatives. Certain government standards and assistance, such as insurance and legal assistance in negotiations and minimum pricing, would therefore be helpful in ensuring producers are able to negotiate the best possible contracts.

National governments in countries such as Tanzania and Sierra Leone have promoted properly negotiated contract farming with small-scale producers and joint ventures (shared equity) with legally recognized community organizations. The government of Tanzania is developing standards for biofuels investments that include provisions for 
involvement of local small-scale producers, and a new policy in Sierra Leone requires that $5-20 \%$ of shares be held by Sierra Leoneans and that outgrower schemes be used (Cotula et al., 2009). Ethiopia could therefore work to improve incentives and services that encourage successful forms of contract farming and joint ventures. Foreign investors could also seek to create more robust and participatory business models where national legislation is weak in order to pre-empt local conflict and international criticism.

Land contracts must also be structured to maximize the investment's contribution to jobs, government revenue, and rural infrastructure. This includes devising incentive systems to promote inclusive business models and requiring investors to commit to a job-creation strategy that prioritizes jobs for affected communities in areas of infrastructure development, public revenues, and other aspects essential to sustainable development. In reviewing a variety contracts in SSA, Cotula et al. (2009) noted that "commitments on infrastructure development seem prominent in some deals-whether under the terms of the contract or applicable national legislation" (p. 81). From requiring the investor to develop and maintain irrigation outside the project area to commitments to pursue labour-intensive business models, the terms and conditions of a contract can have a significant impact on the project's outcomes. Ethiopia's lack of requirements for rural infrastructure development and use of local labour on the part of the investor could therefore be significantly improved.

That said, in examining six projects in Ethiopia to determine how other commitments, such as project timelines, were subject to compliance, Cotula et al. (2009) found that the government tracked and followed up on investors' compliance with commitments and made it a condition for continued enjoyment of leased land (p. 82). For example, one land contract required project activities be initiated within six months of the land transfer, and non-compliance constituted grounds for terminating the contract. Indeed, many land contracts-some high profile-have been cancelled in Ethiopia due to a lack of compliance with commitments related to project progress. In early 2016, for example, the Ethiopian government cancelled a 2010 lease of roughly 100,000 hectares of land to Karuturi Global Ltd., an Indian company and one of the largest investors in Ethiopia's agricultural industry (Bloomberg, 2016). After five years of development, Karuturi had only developed roughly 1200 hectares, despite a contract term that required development of all 100,000 hectares within two years. Given that many smallholders are displaced in leasing land for large-scale farms, prompt development of these projects and/or interim measures to support smallholders is essential to the delivery of sustainable development outcomes. Creating provisions in this regard and ensuring investor compliance is therefore very important. 


\subsection{Food Security Issue}

With regards to food security, the various socio-economic complexities of Ethiopia's agricultural sector and economy are difficult to reconcile. As of 2009, $22 \%$ of this rural population was dependent on a combination of emergency food aid and safety net programs financed by Western donor countries and international agencies (Rahmato, 2011). Although the government now has a more sophisticated warning system in place that allows for quicker mobilization of food to affected regions, the Ethiopian population is still heavily reliant on foreign aid.

Yet, as the Ethiopian government explores new agricultural investment models with the thought of smallholder food security in mind, it must also consider macroeconomic factors that continue to undermine the country's efforts to alleviate poverty and hunger. As of 2015, Ethiopia's terms of trade were notably unfavourable, given that roughly $90 \%$ of its export portfolio was made up of agricultural commodities-typically sold at declining global prices-whereas manufactured goods constituted $71 \%$ of its import portfolio (Terfassa, 2009; World DataBank, 2016a). The same sources show that although crop prices have increased in recent years, Ethiopia's net trade of goods and services balance has been caught in a downward spiral since 2003, largely due to rising inflation. Additionally, at the behest of the IMF, the government devalued the Ethiopian currency by roughly $20 \%$ in 2010 in an attempt to spur export growth and import substitution development (Lavers, 2012b). The Ethiopian government must now strike a balance between the competing interests of its new export-oriented strategy and the food security needs of its smallholder farmers.

Ethiopia's main commodity exports are coffee, sesame seeds, and edible vegetables. On the other hand, cereal crops, which are an important source of food for Ethiopians, have thus far remained mostly within the domestic market. This is largely due to a 2006 directive that banned exports of cereal crops when food shortages are imminent. However, many studies have found that the short-term benefits of export bans are minimal (Diao, Kennedy, Mabiso, \& Pradesha, 2013). As Porteous (2012) demonstrated, prices in countries where export bans have been introduced continue to track prices in countries where food imports are restricted as a result of the ban, despite trade relations being cut off. He theorized that export bans push exporters to store banned crops in an effort to wait out the price freeze, causing prices in both countries to rise higher than they otherwise would. Other studies have found that when many countries simultaneously enact export bans, it causes price spikes to increase further, to the greater detriment of countries that enacted the ban, given that their national markets continue to track international prices (Martin \& Anderson, 2010; Goetz, Qiu, Gervais, \& Glauben, 2012). 
Many foreign investors are interested in developing agricultural projects outside their country's borders due to food security issues in their country of origin. However, the reconciliation of food security issues in both home and host countries require careful policy responses. For example, the current investment guidelines for the King Abdullah Initiative for Saudi Agricultural Investment Abroad provide for "reasonable percentages" of produce to be exported, so as not to exacerbate food insecurity in host countries (Cotula et al., 2009, p. 87). Similar provisions could be included in the investment policies of recipient countries and/or directly in the land contracts themselves.

\subsection{Consultation with Community}

There is also a need for policy and contract provisions that clearly outline the principles for investors' engagement at the local level, as local consultation is often a key factor to the success of a project and its ability to provide inclusive and sustainable outcomes. Free, prior, and informed consent (FPIC) is an important baseline in ensuring proper consultation. FPIC is formalized through Article 32 of the 2007 UN Declaration on the Rights of Indigenous Peoples (UNDRIP), which established that indigenous people have the right to say "yes" or "no" to proposed developments on their lands (Cotula et al., 2009). It also established that governments are responsible for ensuring that effective systems are in place to monitor and uphold compliance with this principle. Since then, FPIC has been included as a requirement in international agreements, such as the Committee on World Food Security's (CFS) Principles for Responsible Investment in Agriculture and Food Systems. Several countries and companies have also incorporated the principle of FPIC into national or sub-national legislation and business requirements. The methodological issue of how broad consultations must be and over what time period is still under debate. Indeed, one of the main complaints among investors is the long and uncertain period of time required for project negotiation (Cotula et al., 2009).

Despite this lingering issue, several African countries have enacted legislation or policies requiring consultation with local and affected communities as part of the land transfer process (e.g., Ghana, Mozambique, and Tanzania), although implementation remains inconsistent (Cotula et al., 2009). Willingness on the part of governments and companies is needed to conduct adequate consultations during land negotiations. Additionally, experience and guidance on how to shape better practice is also key. In the case of Ethiopia, investors should ensure that understandable information (i.e., project proposals with an explanation of options, impacts, and alternatives) is available to the community when all options are still open. It is also crucial to ensure that initial and follow-up consultations include diverse local interests, particularly those of women, minority ethnic groups, and non-resident people like pastoralists. Ensuring that resultant contracts are legally enforceable and provide for grievance mechanisms will also ensure that local 
people can voice concerns and seek redress throughout the project if necessary (African Union, 2003; Cotula et al., 2009).

With regards to compensation, particularly for smallholders in countries like Ethiopia, where all land is owned by the state, limitations to cover only the loss of harvests and improvements to the land are often inadequate. Such compensation does not take into consideration that it will likely be difficult for the smallholder to find another land parcel of the same quality, particularly when demographic pressures are growing. Shortcomings in project implementation, as outlined above, may also undermine the ability of compensation rates to restore livelihoods. Higher levels of compensation, including some form of in-kind compensation, are therefore necessary in certain contexts, especially where cash compensation is unlikely to restore local livelihoods. Compensatory agreements must also be sensitive to multiple and overlapping land rights that are often held individually or collectively in rural African communities. Conducting consultations with representatives from all groups within the community-especially women, minority ethic groups, and pastoralists - is important for understanding who should receive compensation payments at both the household and group level, as well as between various groups, such as farmers versus pastoralist groups (Cotula et al., 2009). In sum, foreign direct investment in large-scale farming when using inclusive and sustainable approaches to investment can offer lucrative options for investors and important opportunities for vulnerable smallholder producers and recipient countries.

\section{Conclusion}

Although the Ethiopian government has attempted to create legislation that fosters inclusive and sustainable agricultural growth, there are still flaws in its regulatory framework that prevent smallholders and pastoralists from leveraging the full benefits of increased agricultural investments. It is therefore incumbent upon investor state governments to address these governance weaknesses through their own regulatory controls and investment strategies that should aim to deliver development outcomes and mitigate negative outcomes. In the meantime, Ethiopia should also work to improve its regulatory framework to address the weaknesses outlined in this study.

If interested governments are to engage in an agricultural partnership with Ethiopia, a foundation of equitable regulations should guide the activities of investors so as to be fair towards the Ethiopian smallholders and pastoralists. These regulations would mostly govern the investment activities of foreign, state-owned enterprises, as its own private sector plays a much smaller investment role. Foreign investors should also continue to foster strong diplomatic ties with Ethiopia to build a sense of partnership and support for future agricultural projects. Once engaged, foreign states and Ethiopia should work 
together to research and pilot suitable models for smallholder-focused investments that simultaneously deliver increased incomes, food and water security, and surpluses for export. Findings from this work would allow Ethiopia to refine its governance legislation and food-importing countries to further their goal of developing a long-term, stable trade partner that caters to the production and export of food and biofuel crops.

\section{References}

African Union. (2003). Protocol to the African charter on human and peoples' rights on the rights of women in Africa. Retrieved 20 July 2016 from http://www.achpr.org/files/instruments/womenprotocol/achpr_instr_proto_women_eng.pdf

Ali, D. A., Dercon, S., \& Gautam, M. (2007). Property rights in a very poor country: Tenure insecurity and investment in Ethiopia. Policy research working paper, no. 4363. Washington, DC: World Bank.

Altieri, M. A., \& Nicholls, C. I. (2008). Scaling up agroecological approaches for food sovereignty in Latin America. Development, 51(4), 472-480.

Anseeuw, W. (2013). The rush for land in Africa: Resource grabbing or green revolution? South African Journal of International Affairs, 20(1), 159-77.

Baumgartner, P. (2012). Change in trend and new types of large-scale investments in Ethiopia. In T. Allan, M. Keulertz, S. Sojamo, \& J. Warner (Eds.), Handbook of land and water grabs in Africa: Foreign direct investment and food and water security (pp. 176-190). Abingdon: Routledge.

Baumgartner, P., von Braun, J., Abebaw, D., \& Muller, M. (2015). Impacts of large-scale land investments on income, prices, and employment: Empirical analyses in Ethiopia. World Development, 72, 175-190.

Bloomberg (2016). Karuturi challenges Ethiopia decision to cancel farm project. Bloomberg Technology. Retrieved [Retrieved 12 February 2017] from http://www.bloomberg.com/news/articles/2016-01-11/karuturi-challengesethiopian-decision-to-cancel-farming-project

Boone, C. (2007). Property and constitutional order: Land tenure reform and the future of the African state. African Affairs, 106(425), 557-586.

Bossio, D., Erkossa, T., Dile, Y., McCartney, M., Killiches, F., \& Hoff, H. (2012). Water implications of foreign direct investment in Ethiopia's agricultural sector. Water Alternatives, 5(2), 223-242. 
Bues, A., \& Theesfeld, I. (2012). Water grabbing and the role of power: Shifting water governance in the light of agricultural foreign direct investment. Water Alternatives, 5(2), 266-283.

Cotula, L., Vermeulen, S., Leonard, R., \& Keeley, J. (2009). Landgrab or development opportunity? Agricultural investment and international land deals in Africa. IIED.

Deininger, K., Selod, H., \& Burns, A. (2011). The land governance assessment framework: Identifying and monitoring good practice in the land sector. Washington, DC: World Bank Group.

Diao, X., Kennedy, A., Mabiso, A., \& Pradesha, A. (2013). Economywide impact of maize export bans on agricultural growth and household welfare in Tanzania: A dynamic computable general equilibrium model analysis. Discussion Paper 01287. IFPRI.

Ethiopian Ministry of Finance and Economic Development (EMFED) \& National Bank of Ethiopia (NBE). (2010). The Federal Democratic Republic of Ethiopia letter of intent. International Monetary Fund (IMF). Retrieved 20 July 2016 from http://www.imf.org/external/np/loi/2010/eth/100810.pdf

Goetz, L., Qiu, F., Gervais, J., \& Glauben, T. (2012, December). Export restrictions and multiple spatial price equilibria when international prices spike: Export quotas for wheat in Ukraine. Invited Paper, IATRC Annual Meeting, San Diego, USA.

Government of Ethiopia (1975). Proclamation no. 31 of 1975: A proclamation to provide for the public ownership of rural lands. Retrieved 20 July 2016 from http://faolex.fao.org/cgibin/faolex.exe?rec_id=001828\&database=faolex\&search_type=link\&table=result\&l ang=eng\&format_name= $@$ ERALL

Government of Ethiopia (1995). Constitution of the Federal Democratic Republic of Ethiopia. $\begin{array}{llll}\text { Retrieved } & 20 & \text { July } & 2016\end{array}$ http://www.wipo.int/edocs/lexdocs/laws/en/et/et007en.pdf

Herren, H. R., Bassi, A. M., Tan, Z., \& Binns, W. P. (2012). Green jobs for a revitalized food and agriculture sector. New York: Natural Resources Management and Environment Department, Food and Agriculture Organization of the United Nations.

Horne, F., \& Bader, L. (2012). Waiting here for death: Forced displacement and "villagization" in Ethiopia's Gambella region. Human Rights Watch.

Lavers, T. (2012a). Patterns of agrarian transformation in Ethiopia: State-mediated commercialisation and the "land grab." Journal of Peasant Studies, 39(3-4), 795-822.

Lavers, T. (2012b). "Land grab" as development strategy? The political economy of agricultural investment in Ethiopia. Journal of Peasant Studies, 39(1), 105-132. 
Makki, F. (2012) Power and property: Commercialization, enclosures, and the transformation of agrarian relations in Ethiopia. Journal of Peasant Studies, 39(1), 81-104.

Martin, W., and K. Anderson. (2010, December). Trade distortions and food price surges. Contributed paper for the $30^{\text {th }}$ Anniversary Conference of the International Agricultural Trade Research Consortium (IATRC), Berkeley, CA.

Moreda, T. (2015). Listening to their silence? The political reaction of affected communities to large-scale land acquisitions: Insights from Ethiopia. Journal of Peasant Studies, 42(3-4), 517-539.

Özden, M. (2013). The right to land. Geneva: CETIM.

Porteous, O.C. (2012). Empirical effects of short-term export bans: The case of African maize. University of California, Berkeley Working Paper.

Rahmato, D. (2011). Land to investors: Large-scale land transfers in Ethiopia. Addis Ababa: Forum for Social Studies.

Ribot, J. C. (2003). Democratic Decentralization of Natural Resources. In N. Van De Walle, N. Ball., \& V. Ramachandran (Eds.), Beyond structural adjustment: The institutional context of African development (pp. 159-182). Basingtoke: Palgrave Macmillan.

Shepherd, B. (2013). GCC states' land investments abroad: The case of Ethiopia. Qatar: Georgetown University.

Terfassa, B. (2009). Ethiopia's trade and investment policy. In T. Assefa (Ed.), Digest of Ethiopia's national policies, strategies and programs (pp. 283-312). Addis Ababa: Forum for Social Studies.

van den Brink, R. J. E. (2006). Consensus, confusion, and controversy: Selected land reform issues in sub-Saharan Africa. Washington, DC: World Bank Group.

Vermeulen, S., \& Cotula, L. (2010). Over the heads of local people: Consultation, consent, and recompense in large-scale land deals for biofuels projects in Africa. The Journal of Peasant Studies, 37(4), 899-916.

Woertz, E. (2013). The global food crisis and the Gulf's quest for Africa's agricultural potential. In T. Allan, M. Keulertz, S. Sojamo, \& J. Warner (Eds.), Handbook of land and water grabs in Africa: Foreign direct investment and food and water security (pp. 104-119). Abingdon: Routledge.

World DataBank. (2016a). Africa development indicators. Retrieved 15 May 2016 from http://databank.worldbank.org/data/reports.aspx?source=world-developmentindicators 
World DataBank. (2016b). World development indicators. Available 15 May 2016 from http://databank.worldbank.org/data/reports.aspx?source=world-developmentindicators

World Food Programme (WFP). (2016). Drought in Ethiopia: 10 million people in need. Retrieved 20 July 2016 from https://www.wfp.org/stories/drought-ethiopia-10million-people-need

i Hany Besada is Deputy Executive Director at the Diamond Development Initiative, Senior Research Fellow with the United Nations and Research Professor, Carleton University and Senior Fellow at the University of Ottawa.

ii This research was supported by the Centre on Governance in collaboration with the Qatar Foundation's National Priority Research Program (NPRP)-funded project, entitled "Governance of Natural Resources in Africa: Advancing a Qatari Perspective and Economic Diversification". NPRP No.: 6-1272-5-160. 